\title{
Халіфе Рабі
}

Харківський національний університет міського господарства імені О.М. Бекетова, Украӥна

\section{ВИЗНАЧЕННЯ ЙМОВІРНОСТІ РУЙНУВАННЯ СИСТЕМИ «СИПУЧЕ ТІЛО - КОНСТРУКЦІЯ» ПРОТИ ЗРУШЕННЯ}

У статті пропонується методика визначення ймовірності руйнування системи «сипуче тіло конструкиія» проти зрушення з використанням методу статистичних випробувань (Монте-Карло). Виконано тестовий приклад у середовищі Маthcad. Отримані значення ймовірності руйнування та коефіцієнти безпеки системи проти зрушення для трьох випадків.

Ключові слова: система «сипуче тіло - конструкція», метод Монте-Карло, ймовірність руйнування, функиія граничного стану, квантіль.

\section{Постановка проблеми}

Потреба у сучасних наукоємних моделях оцінки надійності будівельних конструкцій, а особливо системи «сипуче тіло - конструкція» стоїть зараз дуже гостро у силу того, що така оцінка стала обов'язковою при проектуванні. Існуючий пробіл відсутність алгоритмів визначення надійності складної системи й призвано заповнити дане дослідження.

\section{Аналіз останніх досліджень і публікацій}

В системі Сврокодів був розроблений ряд нормативних документів, що регламентують імовірнісний підхід до будівельних конструкцій i споруд [1-2]. Проблеми оцінки надійності та безпеки будівельних конструкцій розглянуті в роботах O.I. Вайнберга [3], О.В. Кічаєвої [4], А.І. ЛантухаЛященка [5], О.С. Личова [6], В.Д. Райзера [7], А.Р. Ржаніцина [8], А.В. Перельмутера [9], С.Ф. Пічугіна [10], A. Ang [11], J.R. Benjamin [12], C.A. Cornell [11], O. Ditlevsen [14], S.K. Durairaj [15], D.M. Frangopol [16, 17], N.P. Ноеј [18] та багатьох інших вітчизняних та закордонних вчених.

Метою статті $є$ розробка методики визначення ймовірності руйнування системи «сипуче тіло конструкція» проти зрушення 3 використанням методу статистичних випробувань (Монте-Карло).

\section{Виклад основного матеріалу}

Моделювання за методом Монте-Карло є автоматизованою математичною методикою, призначеною для урахування ризику в процесі кількісного аналізу і прийняття рішень. В рамках методу МонтеКарло аналіз ризику виконується за допомогою моделей можливих результатів. При створенні таких моделей будь-який чинник, якому властива невизначеність, замінюється діапазоном значень - розподілом ймовірностей. Потім виконуються багаторазові розрахунки результатів, причому кожен раз використовується інший набір випадкових значень функцій ймовірності. Для коректного моделювання необхідно достатньо значну кількість перерахунків - в залежності від кількості невизначеностей i встановлених для них діапазонів. Моделювання за методом Монте-Карло дозволяє отримати розподіли значень можливих наслідків.

При використанні розподілів ймовірностей змінні можуть мати різні ймовірності настання різних наслідків. Розподіли ймовірностей є більш реалістичним способом опису невизначеності змінних в процесі аналізу ризику. Для викладених нижче задач використовується нормальний розподіл.

Поняття надійності елемента вводиться в класичному сенсі, як ймовірність того, що не буде досягнуто граничного стану:

$$
P=\operatorname{Prob}[S(X)=(R(X)-Q(X))>0],
$$

де $S$ - резерв узагальненої опірності споруди в граничному стані:

$R$ - випадкова змінна - узагальнений опір елемента; $Q$ - випадкова змінна - узагальнене навантаження елемента.

Фундаментальне твердження (1) використовується в припущенні обмежень:

- функції з (1): $R(X)=R, Q(X)=Q, S(X)=S \epsilon$ випадковими змінними;

- закон розподілу змінних $R, Q, S \in$ нормальним;

- випадкові змінні $R, Q$ між собою не корелюють.

У відповідності з нормативним документом 3 проектування підпірних стінок ДСТУ-Н Б В.2.131:2014 можемо записати, що узагальнений резерв міцності $\mathrm{S}$, або функція граничного стану, який $€$ функцією випадкових величин $F_{s d}$ та $F_{u d}$, буде дорівнювати: 


$$
S=\frac{\gamma_{c} F_{u d}}{\gamma_{n}}-F_{s d}
$$

де $F_{s d}$ - зрушуюча сила, що дорівнює сумі проекції всіх зрушувальних сил на горизонтальну площину; $F_{u d}$ - утримуюча сила, що дорівнює сумі проекцій всіх утримуючих сил на горизонтальну плоскість; $\gamma_{c}$ - коефіцієнт умов роботи грунту основи: для пісків, окрім пилуватих - 1; для пилуватих пісків, а також глинистих грунтів в стабілізованому стані - 0,9; для глинистих грунтів в нестабілізованому стані - 0,85 ; для скельних, невивітрелих і слабовивітрелих грунтів -1 ; вивітрилих - 0,9; сильновивітрилих $-0,8$;

$\gamma_{n}$ - коефіцієнт надійності за призначенням споруди згідно з ДБН В.1.2-14.

Стійкість проти зсуву буде забезпечена, якщо:

$$
S \geq 0
$$

Сили $F_{s d}$ та $F_{u d}$ залежать від різноманітних випадкових параметрів зрушення, тому ці сили $\epsilon$ випадковими величинами.

Для визначення ймовірності стійкості підпорної стіни проти зрушення пропонується використання методу статистичних випробувань (Монте-Карло) із застосуванням прийнятої нормативної методики розрахунку. Згідно цього методу необхідно виконати $N$ статистичних випробувань, для кожного з котрих будемо виконувати розрахунки згідно з наступним алгоритмом.

1. Задаємося випадковими ймовірностями розрахункових навантажень на підпірну стіну: складових від горизонтального тиску грунту $P_{E_{h}}$ та горизонтального тиску від навантаження $P_{E_{q h}}$ (у випадку його наявності).

2. За відомими значеннями $P_{E_{h}}$ та $P_{E_{q h}}$ знаходимо квантілі - випадкові значення складових горизонтального тиску на підпірну стіну від грунту і навантаження: $E_{h}$ та $E_{q h}$.

3. Визначаємо випадкове значення сили зсуву $F_{s d}$.

4. Задаємося випадковими ймовірностями утримуючих сил: $P_{G_{s t}}, P_{E_{v}}, P_{E_{q v}}, P_{E_{p}}$.

5. За відомими значеннями $P_{G_{s t}}, P_{E_{v}}, P_{E_{q v}}, P_{E_{p}}$ визначаємо квантілі сил $G_{s t}, E_{v}, E_{q v}, E_{p}$.

6. Визначаємо випадкові значення утримуючої сили $F_{\text {ud }}$ (для трьох випадків).

8. Обчислюємо значення функції граничного стану $S$ по формулі (25).

9. Перевіряємо виконання умови $S \geq 0$.

Після виконання всіх $N$ випробувань обчислюється імовірність невиконання умови стійкості підпірної стіни проти зрушення як відношення числа випробувань $n$, при яких $S<0$, до числа всіх випробувань $N$. Відзначимо, що число випробувань $N$, має бути досить великим, щоб більш точно визначити значення $S$, в цьому випадку число випробувань бралося $N=1 \times 10^{5}$. Розрахунки виконувались в середовищі Mathcad (версія 15.0).

Приклад розрахунку. Обчислимо ймовірність імовірності невиконання умов стійкості підпірної стіни проти зрушення з наступними параметрами: $H$ (вертикальна проекція стіни) х $B$ (горизонтальна проекція стіни) $=8 \times 4$ м, довжина $l=1 \mathrm{M}$, у якості матеріалу стінки прийнятий монолітний залізобетон класу С20/25. Приймаємо, що поверхня грунту горизонтальна, тобто $\beta=0$, грунт - незв'язний $(\mathrm{c}=0)$. У таблиці 1 наведені детерміновані величини, а в таблиці 2 - імовірнісні характеристики функцій нормального розподілу випадкових величин. Коефіцієнт варіації узагальненого силового впливу вертикальних сил для даного випадку обчислений заздалегідь i складає $\mathrm{v}=0,199$. Результати розрахунків представлені в табл. 3 та на рис. 1 i 2 .

Таблиця 1.

Детерміновані величини

\begin{tabular}{|l|c|c|c|}
\hline Найменування параметра & Позн. & $\begin{array}{c}\text { Один. } \\
\text { вимір. }\end{array}$ & Значення \\
\hline Довжина & $l$ & м & 1,0 \\
\hline Товщина підпірної стіни & $t$ & м & 0,2 \\
\hline $\begin{array}{l}\text { Вертикальна проекція } \\
\text { стіни }\end{array}$ & $H$ & м & 10,0 \\
\hline $\begin{array}{l}\text { Горизонтальна проекція } \\
\text { стіни }\end{array}$ & $B$ & м & 5,5 \\
\hline $\begin{array}{l}\text { Глибина затиснення } \\
\text { підпірної стіни нижче дна } \\
\text { котловану }\end{array}$ & $d$ & м & 1,5 \\
\hline $\begin{array}{l}\text { Коефіцієнт активного } \\
\text { горизонтального тиску }\end{array}$ & $K_{a}$ & & 0,37 \\
\hline $\begin{array}{l}\text { Коефіцієнт пасивного } \\
\text { горизонтального тиску } \\
\text { грунту }\end{array}$ & $K_{p}$ & & 0,102 \\
\hline
\end{tabular}

Таблиця 2.

Імовірнісні характеристики функцій нормального

\begin{tabular}{|c|c|c|c|c|}
\hline Параметр & Позн. & $\begin{array}{l}\text { Один. } \\
\text { вим. }\end{array}$ & $\begin{array}{c}\text { Матем. } \\
\text { очікув., } \\
\mu\end{array}$ & $\begin{array}{l}\text { Серед.- } \\
\text { квадрат. } \\
\text { відх., } \sigma\end{array}$ \\
\hline $\begin{array}{l}\text { Питома вага } \\
\text { залізобетонних } \\
\text { конструкцій }\end{array}$ & $\gamma_{b}$ & $\kappa \mathrm{H} / \mathrm{m}^{3}$ & 25,0 & 0,75 \\
\hline $\begin{array}{l}\text { Питома вага грунту } \\
\text { засипки }\end{array}$ & $\gamma_{I}^{\prime}$ & $\kappa \mathrm{H} / \mathrm{M}^{3}$ & 15,0 & 1,5 \\
\hline $\begin{array}{l}\text { Питома вага грунту } \\
\text { непорушеного } \\
\text { складу }\end{array}$ & $\gamma_{I}$ & $\kappa \mathrm{H} / \mathrm{M}^{3}$ & 18,0 & 1,44 \\
\hline $\begin{array}{l}\text { Кут внутрішнього } \\
\text { тертя грунту }\end{array}$ & $\varphi_{I}$ & град. & 30 & 3 \\
\hline $\begin{array}{l}\text { Постійне } \\
\text { навантаження від } \\
\text { ваги грунту у } \\
\text { природному } \\
\text { заляганні }\end{array}$ & G2 & кПа & 18,0 & 1,44 \\
\hline $\begin{array}{l}\text { Постійне } \\
\text { навантаження від } \\
\text { засипки }\end{array}$ & G3 & кПа & 15,0 & 1,5 \\
\hline $\begin{array}{l}\text { Змінне } \\
\text { навантаження від } \\
\text { рівномірно } \\
\text { розподіленого } \\
\text { навантаження }\end{array}$ & $Q 1$ & кПа & 10,0 & 2,0 \\
\hline
\end{tabular}
розподілу 


\begin{tabular}{|c|c|c|c|c|}
\hline $\begin{array}{l}\text { Величина сили } \\
\text { зсуву }\end{array}$ & $F_{s d}$ & кН & 402,195 & 80,0 \\
\hline $\begin{array}{l}\text { Величина } \\
\text { утримуючої сили } 3 \\
\text { урахуванням } \\
\text { коефіцієнтів } \\
\left(\text { для } \omega=0^{\circ} \text { ) }\right.\end{array}$ & $F_{u d l}$ & кН & 523,961 & 24,1 \\
\hline $\begin{array}{l}\text { Величина } \\
\text { утримуючої сили } 3 \\
\text { урахуванням } \\
\text { коефіцієнтів } \\
\left(\text { для } \omega=15^{\circ}\right)\end{array}$ & $F_{u d 3}$ & кН & 565,945 & 26,03 \\
\hline $\begin{array}{l}\text { Величина } \\
\text { утримуючої сили } 3 \\
\text { урахуванням } \\
\text { коефіцієнтів } \\
\left(\text { для } \omega=30^{\circ}\right) \\
\end{array}$ & $F_{u d 5}$ & кН & 614,341 & 28,26 \\
\hline
\end{tabular}

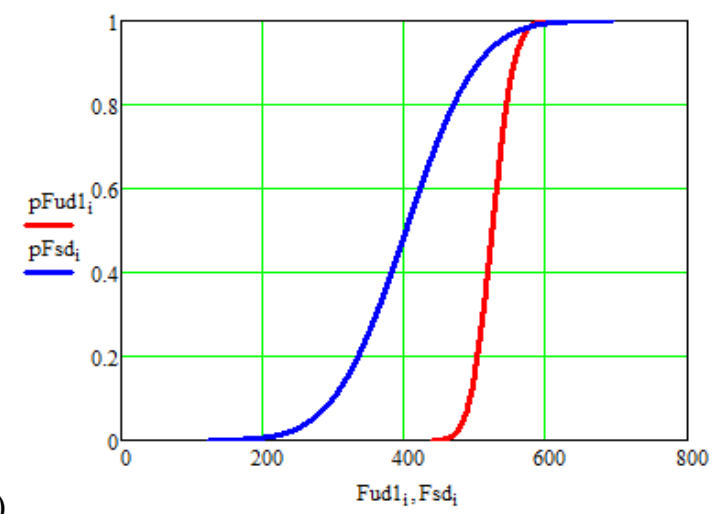

a)

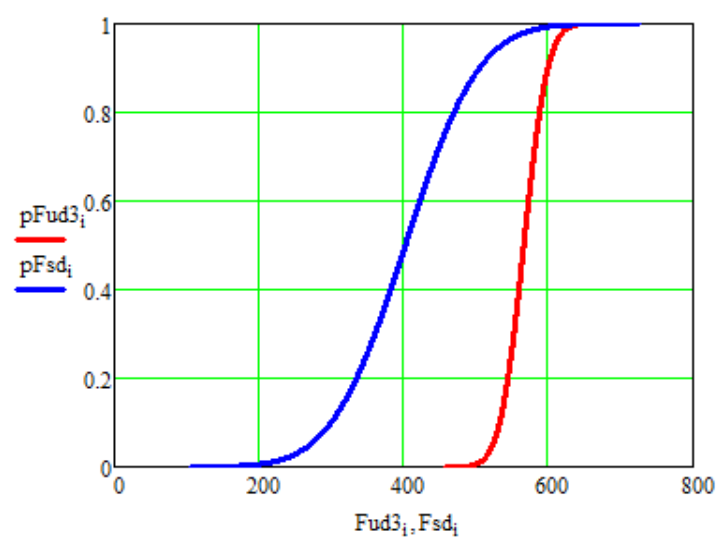

б)

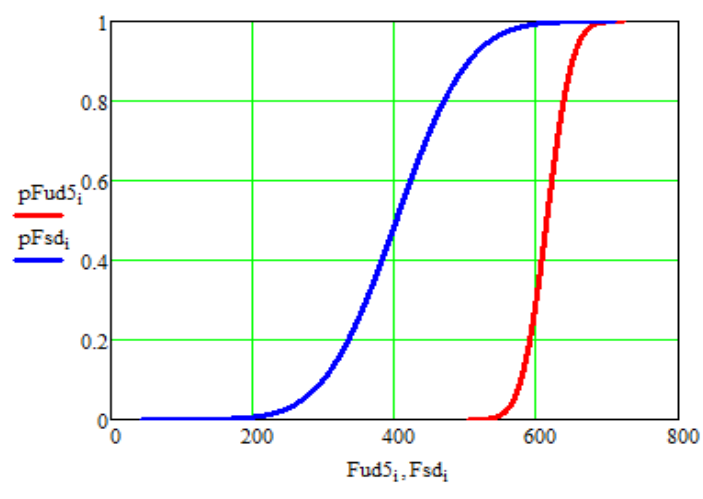

B)

Рис. 1. Функції розподілу: зрушувальної сили $\mathrm{F}_{s d} \mathrm{i}$ утримуючої сили $F_{u d 1}$ для випадку 1 (а), 2 (б), 3 (в) відповідно $\left(\omega=0,15^{\circ}, 30^{\circ}\right)$ a)

\section{Висновки}

1. Розроблено методику визначення ймовірності руйнування системи «сипуче тіло - конструкція» проти зрушення за статистичним методом МонтеКарло.

2. Виконано розрахунки 3 визначення ймовірності руйнування системи «сипуче тіло конструкція» проти зрушення за статистичним методом Монте-Карло (табл. 3). 3'ясовано, що значення ймовірності руйнування системи «сипуче тіло - конструкція» проти зрушення за базовий строк служби може знаходитись в діапазоні $1 \times 10^{-5} \ldots 1 \times 10^{-3}$.
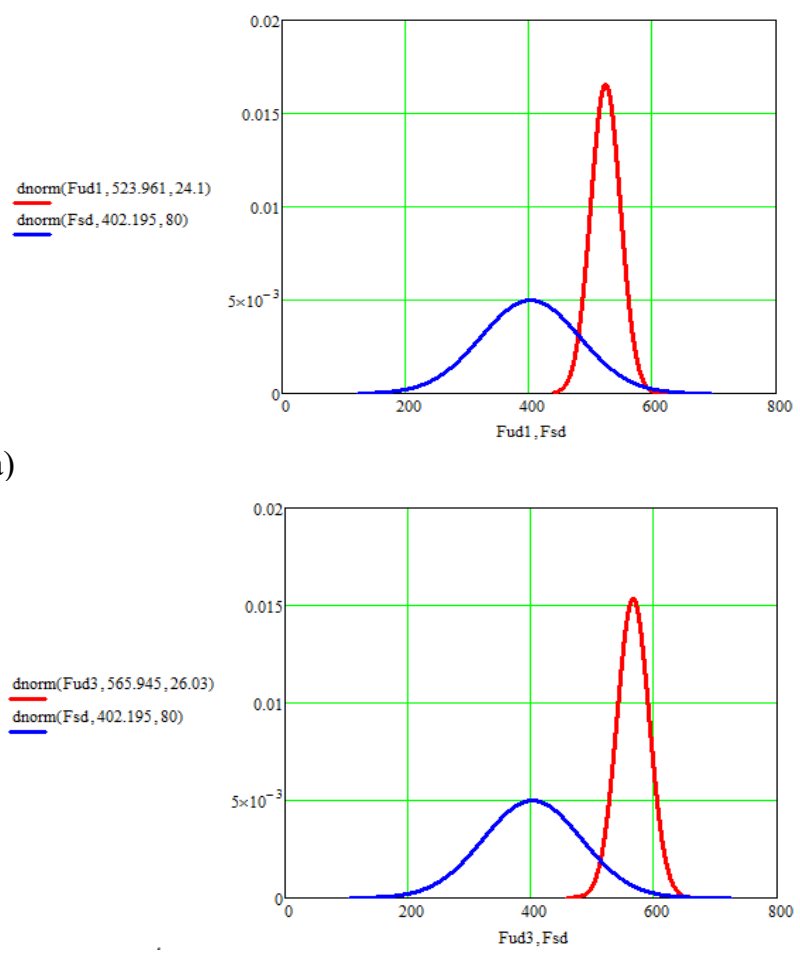

б)

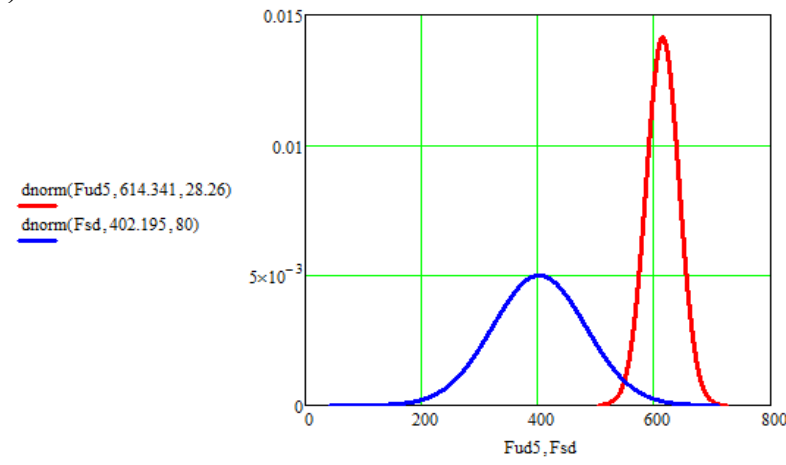

в)

Рис. 2. Щільності ймовірності розподілу зрушувальної сили $\mathrm{F}_{s d}$ і утримуючої сили $F_{u d l}$ для випадку 1 (а), 2 (б), 3 (в) відповідно $\left(\omega=0,15^{\circ}, 30^{\circ}\right)$ 
Таблиця 3.

Результати розрахунків імовірності руйнування системи «сипуче тіло - конструкція» проти зрушення

\begin{tabular}{|l|c|c|}
\hline \multicolumn{1}{|c|}{ Найменування величин } & Ймовірність & $\beta$ \\
\hline $\begin{array}{l}\text { Iмовірність руйнування } \\
\text { системи проти зрушення } \\
\text { (відповідно для 1-го, 2-го і 3- } \\
\text { го випадків) }\end{array}$ & $1 \times 10^{-5}$ & 4,27 \\
\cline { 2 - 3 } & $1 \times 10^{-3}$ & 2,95 \\
\hline $\begin{array}{l}\text { Рекомендовані мінімальні } \\
\text { величини за }\end{array}$ & 4,27 \\
$\begin{array}{l}\text { ДСТУ-Н Б В.1.2-13:2008 (EN } \\
\text { 1990:2002, IDN) [13], ISO } \\
\text { 2394-1998 [14] }\end{array}$ & $1 \times 10^{-4}$ & 3,8 \\
\hline
\end{tabular}

\section{Перспективи подалыших розвідок}

Було б цікавим також за допомогою ймовірнісних методів розробити алгоритми ймовірності руйнування підпірних стін внаслідок втрати несучої здатності грунтової основи, міцності скельної основи, втрати міцності елементів конструкцій вузлів і з'єднань, а також ймовірності перевищення рівня деформацій основи.

\section{Література}

1. ENV 1991-1. Eurocode 1: Basis of Design and Actions of Structures/ Part 1: Brussels: CEN. 1993. -87 p.

2. ISO 2394:2015. General principles on reliability for structures - International Organization for Standardization. 2015. $-111 p$.

3. Вайнберг, А.И. Надежность и безопасность гидротехнических сооружений. Избранные проблемы : моногр. / А.И. Вайнберг - Х., 2008. - 304 c.

4. Кічаєва, О.В. Наукові засади очінювання надійності та безпеки системи «будівля - основа». Дис. ... докт. техн. наук / О.В. Кічасва. - Х., 2018. - 462 c.

5. Лантух-Лященко, А.І. Сучасні теоретичні засади визначення надійності мостів / А.І. Лантух-Лященко : Зб. наук. праць НТУ «Автомобільні дороги і дорожне будівництво». -K., 2002. - Bun. 24. - C. 155-165.

6. Лычев, А.С. Надежность строительных конструкций : учеб. пос. / А.С. Лычев-М.: АСВ, 2008. 184 c.

7. Райзер, В.Д. Методы теории надежности в задачах нормирования расчетных параметров строительных конструкиий / В.Д. Райзер. - М.: Стройиздат, 1986. $192 c$.

8. Ржаницын, А.Р. Теория расчета строительных конструкиий на надежность / А.P. Ржанищьын. - М.: Стройиздат, 1978. - 239 c.

9. Перельмутер, А.В. Избранные проблемы надежности и безопасности строительных конструкиий / А.В. Перельмутер. - М.: АСВ, 2007. -185 c.

10. Пичугин, С.Ф. Надежность строительных конструкций производственных зданий : моногр. / С.Ф. Пичугин. - Полтава: ООО «Асми», 2009. - 452 c.

11. Babaev V.N. Rational design of retaining walls / V.N. Babaev, V.S. Shmukler, S.H. Feirushah, O.A. Kalmykov, V.M. Zinchenko / BUITEMS "Journal of applied and emerging sciences”. - 2012. - Vol. 3, Issue 1. - P. 94-121.
12. Benjamin, J.R., Cornell, C.A. Probability. (1970). Statistics, and Decision for Civil Engineers. New York: McGraw-Hill. $684 \mathrm{p}$.

13. Kalmykov O. Search for rational contour of back surface of retaining wall / O. Kalmykov, R. Khalife, A. Grabowski // AIP Conference Proceedings. -2019.

14. Ditlevsen, O., Madsen, H.O. (1996) Structural Reliability Methods. Chichester: John \& Wiley Sons Ltd. 185 p.

15. Durairaj, S.K., Ong, S.K., Nee, A.Y.C., Tan, R.B.H. (2002). Evaluation of Life Cycle Cost. Analysis Methodologies. Corporate Environmental Strategy. Vol. 9. No. 1, 30-39.

16. Shmukler V. About the possibility for control of nature of seismic effect of bulky material on lateral surfaces / V.S. Shmukler, S.H. Feirusha, O. Kalmykov, R. Khalife // ZANCO Journal of Pure and Applied Sciences, p. 250-256.

17. Geotechnical Safety and Pisk V. Fifth International Symposium on Geotechnical Safety and Risk (ISGSR2015)/ Rotterdam, Netherlands, 13-16 October 2015. p. 1003.

18. Hoej, N.P. (2001). Risk and Safety Considerations at Different Project Phases. Safety, risk, and reliability - trends in engineering. International Conference. Malta. 1-8.

\section{References}

1. ENV 1991-1. Eurocode 1: Basis of Design and Actions of Structures/ Part 1: Brussels: CEN. 1993. -87 p.

2. ISO 2394:2015. General principles on reliability for structures - International Organization for Standardization. 2015. - 111 p.

3. Wainberg, A.I. (2008). Reliability and safety of hydraulic structures. Selected problems: monograph. $304 \mathrm{p}$.

4. Kichaeva, O.V. (2018). Scientific principles of assessing the reliability and safety of the system "building - foundation". Dis. ... Dr. tech. scienses. -462 p.

5. Lantukh-Lyashchenko, A.I. (2002) Modern theoretical principles of determining the reliability of bridges. Coll. Science. Proceedings of NTU "Roads and road construction", Vol. 24. 155-165.

6. Lychev, A.S. (2008) Reliability of building structures: tutorial. $184 \mathrm{p}$.

7. Raiser, V.D. (1986). Methods of the theory of reliability in the tasks of standardizing the design parameters of building structures. $192 \mathrm{p}$.

8. Rzhanitsyn, A.R. (1978). The theory of calculation of building structures for reliability. $239 \mathrm{p}$.

9. Perelmuter, A.V. (2007). Selected problems of reliability and safety of building structures. $185 \mathrm{p}$.

10. Pichugin, S.F. (2009). Reliability of building structures of industrial buildings: monograph. $-452 \mathrm{p}$.

11. Babaev V.N. Rational design of retaining walls / V.N. Babaev, V.S. Shmukler, S.H. Feirushah, O.A. Kalmykov, V.M. Zinchenko / BUITEMS "Journal of applied and emerging sciences". - 2012 - Vol. 3, Issue 1 - P. 94-121.

12. Benjamin, J.R., Cornell, C.A. Probability (1970). Statistics, and Decision for Civil Engineers. New York: McGraw-Hill. $684 \mathrm{p}$.

13. Kalmykov O. Search for rational contour of back surface of retaining wall / O. Kalmykov, R Khalife, A. Grabowski // AIP Conference Proceedings. - 2019.

14. Ditlevsen, O., Madsen, H.O. (1996). Structural Reliability Methods. Chichester: John \& Wiley Sons Ltd. 185 p. 
15. Durairaj, S.K., Ong, S.K., Nee, A.Y.C., Tan, R.B.H. (2002). Evaluation of Life Cycle Cost. Analysis Methodologies. Corporate Environmental Strategy. Vol. 9. No. 1, 30-39.

16. Shmukler V. About the possibility for control of nature of seismic effect of bulky material on lateral surfaces / V.S. Shmukler, S.H. Feirusha, O. Kalmykov, R. Khalife // ZANCO Journal of Pure and Applied Sciences, p. 250-256.

17. Geotechnical Safety and Pisk V. Fifth International Symposium on Geotechnical Safety and Risk (ISGSR2015)/ Rotterdam, Netherlands, 13-16 October 2015. p. 1003.

18. Hoej, N.P. (2001). Risk and Safety Considerations at Different Project Phases. Safety, risk, and reliability - trends in engineering. International Conference. Malta. 1-8.
Рецензент: д-р техн. наук, доцент, професор кафедри механіки грунтів, фундаментів та інженерної геології О.В. Кічаєва, Харківський національний університет міського господарства імені О.М. Бекетова, Україна.
Автор: Халіфе РАБІ
аспірант, Харківський національний університет міського господарства імені О.М. Бекетова
E-mail-Sama4eng@gmail.com
ID ORCID: https://orcid.org/0000-0002-8800-0325

\title{
DETERMINATION OF THE PROBABILITY OF SYSTEM DESTRUCTION "LOOSE BODY - CONSTRUCTION" AGAINST SHIFT
}

\author{
Khalife Rabih
}

O.M. Beketov National University of Urban Economy in Kharkiv, Ukraine

The need for modern science-intensive models for assessing the reliability of building structures, and especially the system "loose body - structure" is now very acute due to the fact that such an assessment has become mandatory in the design. The existing gap is the lack of algorithms for determining the reliability of a complex system and is intended to fill this study.

The aim of the article is to develop a method for determining the probability of failure of the system "bulk body - structure" against displacement using the method of statistical tests (Monte Carlo).

To determine the probability of stability of the retaining wall against displacement, it is proposed to use the method of statistical tests using the accepted normative method of calculation. According to this method, it is necessary to perform $N$ statistical tests, for each of which we will perform calculations according to the algorithm described in the article.

A method for determining the probability of failure of the system "loose body-structure" against the shift by the statistical method of Monte Carlo. A test example was performed in the Mathcad environment.

Calculations were performed to determine the probability of failure of the system "loose body - structure" against the shift by the statistical method of Monte Carlo. It was found that the value of the probability of failure of the system "loose body - structure" against the shift over the base service life may be in the range of $1 \times 10^{-5} \ldots 1 \times 10^{-3}$.

It would also be interesting to use probabilistic methods to develop algorithms for the probability of failure of retaining walls due to loss of bearing capacity of the soil base, strength of the rock base, loss of strength of structural elements and joints, as well as the probability of exceeding the deformation of the base.

Keywords: "loose body - structure" system, Monte Carlo method, failure probability, limit state function, quantile. 